\title{
QUANTIFICATION AND MOLECULAR CHARACTERIZATION OF SALMONELLA ISOLATED FROM FOOD SAMPLES INVOLVED IN SALMONELLOSIS OUTBREAKS IN RIO GRANDE DO SUL, BRAZIL
}

\author{
Lisandra Mürmann; Maria Cecília dos Santos ; Solange Mendes Longaray²; Jane Mari Corrêa Both²; \\ Marisa Cardoso ${ }^{1 *}$
}

\begin{abstract}
${ }^{1}$ Departamento de Medicina Veterinária Preventiva, Faculdade de Veterinária, Universidade Federal do Rio Grande do Sul, Porto Alegre, RS, Brasil; ${ }^{2}$ Instituto de Pesquisas Biológicas, Laboratório Central do Estado, Fundação Estadual de Produção e Pesquisa em Saúde, Secretaria Estadual da Saúde do Estado do Rio Grande do Sul, Porto Alegre, RS, Brasil.
\end{abstract}

Submitted: October 26, 2007; Returned to authors for corrections: February 13, 2008; Approved: July 13, 2008.

\begin{abstract}
Data concerning the prevalence and populations of Salmonella in foods implicated in outbreaks may be important to the development of quantitative microbial risk assessments of individual food products. In this sense, the objective of the present study was to assess the amount of Salmonella sp. in different foods implicated in foodborne outbreaks in Rio Grande do Sul occurred in 2005 and to characterize the isolated strains using phenotypic and genotypic methods. Nineteen food samples involved in ten foodborne outbreaks occurred in 2005, and positive on Salmonella isolation at the Central Laboratory of the Health Department of the State of Rio Grande do Sul, were included in this study. Food samples were submitted to estimation of Salmonella using the Most Probable Number (MPN) technique. Moreover, one confirmed Salmonella colony of each food sample was serotyped, characterized by its $\mathrm{XbaI}$-macrorestriction profile, and submitted to antimicrobial resistance testing. Foods containing eggs, mayonnaise or chicken were contaminated with Salmonella in eight outbreaks. Higher counts $\left(>10^{7} \mathrm{MPN}_{\mathrm{g}} \mathrm{g}^{-1}\right)$ of Salmonella were detected mostly in foods containing mayonnaise. The isolation of Salmonella from multiple food items in five outbreaks probably resulted from the cross-contamination, and the high Salmonella counts detected in almost all analyzed samples probably resulted from storing in inadequate temperature. All strains were identified as $S$. Enteritidis, and presented a unique macrorestriction profile, demonstrating the predominance of one clonal group in foods involved in the salmonellosis outbreaks. A low frequency of antimicrobial resistant $S$. Enteritidis strains was observed and nalidixic acid was the only resistance marker detected.
\end{abstract}

Key-words: Salmonella, foodborne outbreak, quantification, PFGE.

\section{INTRODUCTION}

In Southern Brazil, a high prevalence of Salmonella isolation has been found in pigs (2), pork (6) and pork products (24). In opposite to that, pork is rarely involved in salmonellosis outbreaks reported in this region $(8,25)$. Data collected in Rio Grande do Sul, during the period of 1997 to 1999 , pointed salad prepared with homemade mayonnaise as the most often implicated food in salmonellosis outbreaks, accounting for
$42.45 \%$ of all identified food vehicles (8). Factors responsible for the discrepancy between Salmonella prevalence in pork and the frequency of foodborne outbreaks attributed to pork consumption need to be better investigated.

It is well documented that exposure to larger quantities of foodborne pathogens usually results in a greater risk to human health $(14,18,34)$. Consequently, the final concentration of Salmonella in food is an important parameter contributing to overall disease risk. In this sense, data on the prevalence and

*Corresponding Author. Mailing address: Faculdade de Veterinária, UFRGS, Av. Bento Gonçalves 9090, 90540-000. Porto Alegre, RS, Brasil. Tel.: +5551-3308-6123, Fax: +55-51-3308-7305. E-mail: mcardoso@ufrgs.br 
populations of Salmonella in foods implicated in outbreaks may be important to the development of quantitative microbial risk assessments of individual products.

Another aspect contributing to the understanding of Salmonella epidemiology is the characterization of the strains involved in outbreaks. Serotyping is traditionally conducted as a first approach in the characterization and usually forms the background for all other typing methods (28). Over the past two decades genotyping has been associated to the traditional typing methods to achieve a better discrimination of strains and to identify bacterial clones (28). Among the molecular methods, pulsed-field gel electrophoresis (PFGE) is considered the standard method for DNA fingerprinting in Salmonella, and has been performed to investigate salmonellosis outbreaks $(11,16,17,21,40)$.

In this sense, the objective of the present study was to assess the amount of Salmonella $\mathrm{sp}$. in different foods implicated in foodborne outbreaks in Rio Grande do Sul occurred in 2005 and to characterize the isolated strains using phenotypic and genotypic methods.

\section{MATERIALAND METHODS}

\section{Food samples}

Nineteen food samples involved in ten foodborne outbreaks occurred in Rio Grande do Sul in 2005, and positive for Salmonella isolation at Laboratório Central da Secretaria Estadual da Saúde (Central Laboratory of State Health Department, LACEN/RS, Porto Alegre, Rio Grande do Sul) were included in this study. Food samples were stored during the analysis period in sterile flasks at $4^{\circ} \mathrm{C}$. Data available for each confirmed salmonellosis outbreak were obtained from the epidemiological investigation report received with the food samples by LACEN.

\section{Salmonella quantification and serotyping}

Food samples were submitted to estimation of Salmonella using the Most Probable Number (MPN) technique as previously described (4) with modifications. From each positive sample, $25 \mathrm{~g}$ were added to $225 \mathrm{~mL}$ of Buffered Peptone Water (BPW). The samples were homogeneized for $1 \mathrm{~min}$ (Stomacher, Interscience, St. Nom, France) and decimal dilutions up to $10^{-8}$ were prepared in BPW. Triplicate tubes of all dilutions were incubated at $35^{\circ} \mathrm{C}$ for $18 \mathrm{~h}$. From each dilution tube, aliquots of $0.1 \mathrm{~mL}$ were transferred to $9.9 \mathrm{~mL}$ of Rappaport-Vassiliadis broth (Merck, Darmstadt, Germany). Following incubation on the selective enrichment media at $42^{\circ} \mathrm{C}$ for $24 \mathrm{~h}$, samples were streaked onto XLT4 (Difco, Sparks, USA) agar. After $24 \mathrm{~h}$ incubation at $37^{\circ} \mathrm{C}$, suspected colonies from each plate were confirmed as Salmonella by biochemical tests and agglutination using poly O-antiserum (Probac, São Paulo, Brazil). The number of tubes in each dilution, from which colonies were confirmed as Salmonella, was used to estimate Salmonella counts using the MPN table (1). One confirmed Salmonella colony of each food sample was serotyped at Fundação Oswaldo Cruz (Brazilian Salmonella Reference Institute, Rio de Janeiro, Brazil).

\section{Macrorestriction analysis}

Genomic DNA of one Salmonella isolate obtained from each positive food sample was extracted as previously described $(22,36)$. Slices of DNA-containing agarose plugs were digested with 20 units of $X b a \mathrm{I}$ (Promega, Madison, USA) at $37^{\circ} \mathrm{C}$ for $18 \mathrm{~h}$. The respective fragments were separated by pulsed field gel electrophoresis (PFGE) in 1\% PFGE-certified agarose gel (BioRad, Hercules, USA) in a CHEF DR II system (BioRad, California, USA) at $5.6{\mathrm{~V} . \mathrm{cm}^{-1}}^{-1}$ with $0.5 \times \mathrm{TBE}$ as the running buffer. In order to avoid the DNA degradation of Salmonella isolates, $50 \mu \mathrm{mol}$ of Thiourea (Acros Organics, Geel, Belgium) was added to the running buffer. The pulse times were increased from 10 to $30 \mathrm{~s}$ during the first $11 \mathrm{~h}$ and subsequently from 30 to $50 \mathrm{~s}$ during the next $13 \mathrm{~h}$. The gel was stained with ethidium bromide ( $2 \mathrm{mg} / \mathrm{mL}$, Sigma, St. Louis, USA) and photographed under UV-illumination. Patterns produced by PFGE were compared using the GelCompar II software package (Applied Maths, Kortrijk, Belgium).

\section{Antimicrobial susceptibility testing}

Antimicrobial resistance was determined by agar disk diffusion tests using disks with the following antimicrobials (Cefar Diagnóstica, São Paulo, Brazil): amikacin $(30 \mu \mathrm{g})$, ampicillin $(10 \mu \mathrm{g})$, cefaclor $(30 \mu \mathrm{g})$, ciprofloxacin $(5 \mu \mathrm{g})$, chloramphenicol $(30 \mu \mathrm{g})$, gentamicin $(10 \mu \mathrm{g})$, nalidixic acid (30 $\mu \mathrm{g})$, tetracycline $(30 \mu \mathrm{g})$, tobramycin $(10 \mu \mathrm{g})$, streptomycin $(10$ $\mu \mathrm{g})$, sulfamethoxazole-trimethoprim $(23.75 / 1.25 \mu \mathrm{g})$, and sulfonamide $(300 \mu \mathrm{g})$. The testing was conducted and evaluated according to the document M100-S15 of the Clinical and Laboratory Standards Institute (7). Escherichia coli ATCC 25922 was used for quality control testing.

\section{RESULTS}

In eight salmonellosis outbreaks analyzed in the present study, a total of 212 people were exposed and 15 patients needed hospitalization. In two outbreaks, epidemiological data regarding the city of origin and/or the number of exposed people were not available (Table 1). The major symptoms observed were fever, diarrhea and abdominal pain, while nausea and vomiting were reported in six outbreaks. The median incubation period varied from 9 to 24 hours, and in most part of the outbreaks, symptoms appeared between 13 and 17 hours after the food ingestion (data not shown).

Foods containing eggs, mayonnaise or chicken were contaminated with Salmonella in eight outbreaks (Table 1). 
Table 1. Salmonella quantification in foods involved in outbreaks in Rio Grande do Sul, Brazil, in 2005.

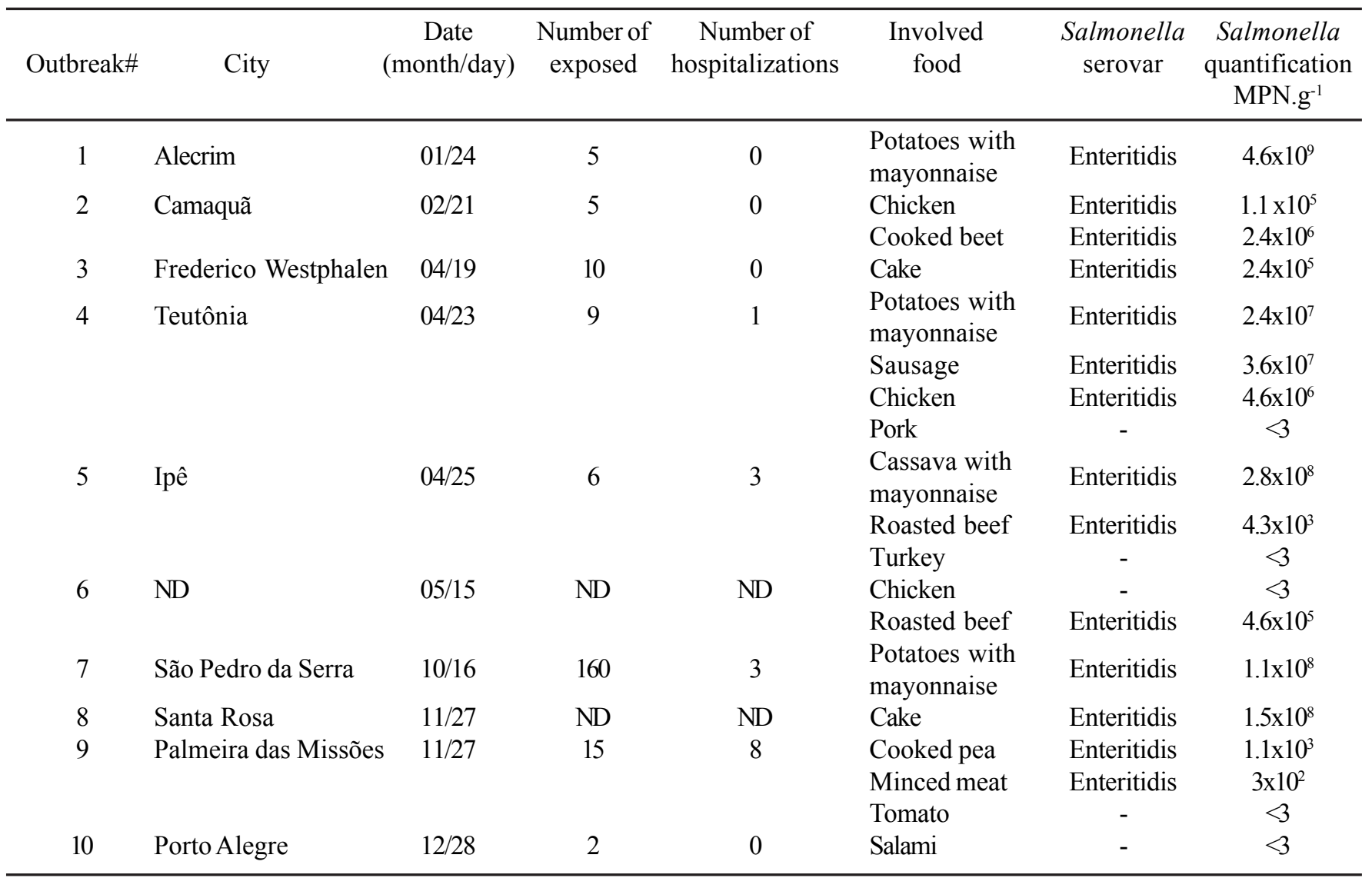

Higher counts $\left(>10^{7}\right.$ MPN.g $\left.{ }^{-1}\right)$ of Salmonella were detected mostly in foods containing mayonnaise. Other food items with high counts were the cake in outbreak \#8, and the pork sausage in outbreak \#4. In five outbreaks more than one food item were positive on Salmonella isolation. In these cases, food items with low as well as high Salmonella counts were detected in a same outbreak.

All fourteen Salmonella strains submitted to serotyping were classified as $S$. Enteritidis and resulted in a single PFGE profile (Fig. 1). Six $S$. Enteritidis strains were resistant only to nalidixic acid, while the remaining eight strains were sensible to all tested antimicrobials (data not shown).

\section{DISCUSSION}

In the present study we analyzed foods collected in ten confirmed salmonellosis outbreaks investigated in Rio Grande do Sul in the year 2005. These outbreaks probably represent a small fraction of all salmonellosis cases that occurred in this region, since the lack of reporting to the sanitary authority and

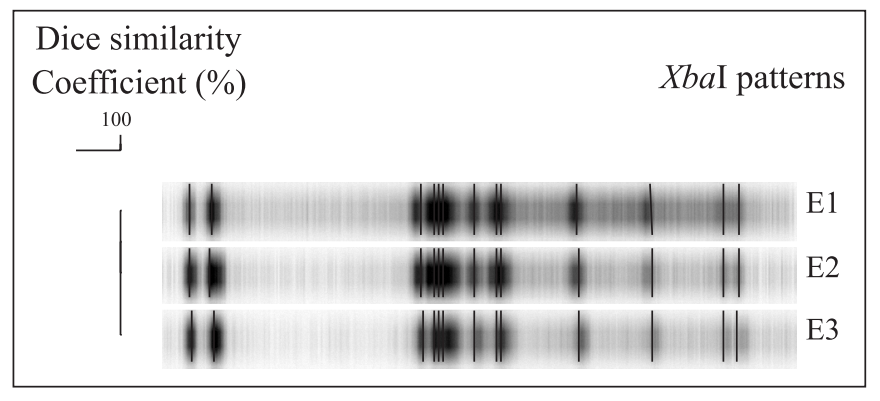

Figure 1. XbaI-macrorestriction profiles identified in Salmonella Enteritidis strains isolated from foods involved in outbreaks in Rio Grande do Sul, Brazil in 2005.

failure on identification of the responsible food is not a rare event in foodborne disease surveillance (35).

Salmonellosis has been the most important foodborne disease, in Rio Grande do Sul, since 1993 (8,25). In most salmonellosis outbreaks investigated in Brazil $(8,25,30)$ and in 
other countries $(3,29)$, foods prepared with eggs were implicated as the Salmonella vehicle. Similarly, in the present study mayonnaise and cakes are among the foods with Salmonella isolation in six outbreaks, and together with chicken are implicated in all except two outbreaks analyzed. In contrast to that, only in outbreak \#4 Salmonella was isolated from pork and pork sausage. However, Salmonella has been frequently isolated from pigs and pork $(2,6,19,24)$, demonstrating that this pathogen circulates throughout the swine production chain. Possible reasons for these conflicting results are the low Salmonella counts found in pork products sampled in Rio Grande do Sul (24), and the habit of preparing pork products well-done, allowing the destruction of any Salmonella that eventually is present in the food.

The isolation of Salmonella from multiple food items in five outbreaks suggests the cross-contamination due to improper manipulation. Moreover, the high Salmonella counts detected in almost all analyzed samples probably resulted from storing foods at ambient temperature for more than two hours or by their inadequate refrigeration. This kind of processing failures has been commonly pointed among the factors contributing for salmonellosis outbreaks in Rio Grande do Sul $(8,25)$. The association of cross-contamination and storing in inadequate temperature can explain the Salmonella counts found on the cooked beet and on the cooked peas in outbreaks \#2 and \#9, respectively. In both outbreaks, animal derived products were also involved, thus the contact with raw animal-derived foods as well as with contaminated surfaces in the kitchen may have allowed the cross-contamination of the cooked foods. Afterwards, the holding of the contaminated cooked foods at ambient temperature permitted the multiplication of Salmonella, which attained high population counts prior the consumption.

The number of involved in an outbreak and the severity of the symptoms are related to susceptibility of the individuals (38), food composition and Salmonella number on the food (13). Moreover, persons who had eaten higher amounts of contaminated foods were found more likely to have shorter incubation periods and higher hospitalization risk (14). Considering that, an infecting dose between $10^{5}$ and $10^{7}$ colony forming units (cfu) is usually accepted for immunocompetent adults (38). Most foods analyzed in the present study had Salmonella counts above the proposed infecting dose.

All Salmonella strains analyzed were serotyped as Enteritidis, demonstrating the predominance of this serovar in foods involved in salmonellosis outbreaks occurring in Rio Grande do Sul in the year 2005. Previous studies reported that $S$. Enteritidis has become the main cause of salmonellosis outbreaks $(9,10,12,23,30,31)$ and this serovar has been also the most prevalent among poultry-related samples in $\operatorname{Brazil}(32,37)$. Furthermore, a high adaptation of $S$. Enteritidis to colonize the chicken oviduct has been proposed, indicating that poultry may be an important reservoir of this pathogen (20).
In spite of being isolated from not related outbreaks, all strains characterized in this study presented a common PFGE pulse-type, demonstrating a clonal relationship among them. In previous studies conducted in Rio Grande do Sul $(26,39)$, strains isolated from poultry and humans have also demonstrated a clonal relationship, which might contribute to elucidate the origin of salmonellosis cases. Since strains from poultry were reported as clonal due to the possible spread of one clone by international trade of breeding lines (33), a common clone causing foodborne outbreaks transmitted by egg products is not unexpectedly. Moreover, predominant PFGE patterns are also found in strains isolated from outbreaks in other countries (17) indicating that common clones may be responsible for the disease cases. Such results reinforce the limited diversity of $S$. Enteritidis strains, and point to the need of further studies to investigate other characteristics of these clones such as survival and colonization capability.

A low frequency of antimicrobial resistant $S$. Enteritidis strains was observed and nalidixic acid was the only resistance marker detected. A shift in the resistance level was observed in $S$. Enteritidis strains isolated in the same region over time $(5,27,39)$. In general, antimicrobial resistance was higher in samples of animal origin than those related to food products, demonstrating the high selective pressure caused by the use of antimicrobials in the food production chain. However, also in poultry samples a reduction on the frequency of resistant strains could be found after 1998, when many antimicrobials were banished for growth promotion in Brazil (39). The reduction of antimicrobial use, occurred in the poultry production chain in recent years, may explain the low frequency of resistance that we found in our study.

On the other hand, the resistance to nalidixic acid reflects the still widespread use of this antimicrobial in poultry therapy in Brazil and other countries. It is a matter of concern, since emergence of resistance to nalidixic acid has been associated to decreased susceptibility to fluoroquinolones, which are used for treatment of human patients suffering of severe salmonellosis cases (15). The prevalence of these strains in foods involved in outbreaks represents a risk of salmonellosis cases caused by strains resistant to the drug used in therapy.

In conclusion, high counts $\left(>10^{3} \mathrm{MPN} \cdot \mathrm{g}^{-1}\right)$ of Salmonella were detected in most foods implicated in the reported salmonellosis outbreaks occurred in 2005 in Rio Grande do Sul. Our results suggest that one PFGE clonal group of $S$. Enteritidis was involved in all those salmonellosis outbreaks.

\section{ACKNOWLEDGEMENTS}

The authors thank to Beatriz M. Falavigna (Fundação Instituto Oswaldo Cruz, Rio de Janeiro, Brazil) for serotyping the Salmonella strains. This study was supported by the Conselho Nacional de Pesquisa - CNPq (L. Mürmann scholarship). 


\section{RESUMO}

\section{Quantificação e perfil molecular de Salmonella isolada de alimentos envolvidos em surtos de salmonelose no Rio Grande do Sul}

Dados sobre a prevalência e a população de Salmonella em alimentos implicados em surtos podem contribuir na condução de análises de risco. Dessa forma, o objetivo desse estudo foi determinar a quantidade de Salmonella sp. presente em alimentos implicados em surtos ocorridos no Rio Grande do Sul em 2005 e caracterizar os isolados por meio de técnicas fenotípicas e genotípicas. Dezenove amostras de alimentos obtidas em dez surtos ocorridos em 2005 e identificadas como positivas para Salmonella no Laboratório Central da Secretaria da Saúde do Estado do Rio Grande do Sul foram incluídas no estudo. A quantificação de Salmonella foi feita pela técnica do Número Mais Provável (NMP). Ao lado disto, uma colônia de Salmonella obtida de cada amostra de alimento foi submetida à sorotipificação, macro-restição com $X b a \mathrm{I}$ e determinação de resistência a antimicrobianos. Salmonella esteve presente em alimentos a base de ovos, maionese e frango em oito surtos. As contagens mais elevadas $\left(>10^{7} \mathrm{NMP}^{-1} \mathrm{~g}^{-1}\right)$ foram detectadas principalmente em alimentos contendo maionese. $\mathrm{O}$ isolamento de Salmonella de vários alimentos em cinco surtos resultou, provavelmente, da contaminação cruzada, enquanto as elevadas contagens encontradas, em quase todos os alimentos, podem ser explicadas por armazenamento em temperatura inadequada. Todos os isolados foram identificados como $S$. Enteritidis, e apenas um perfil foi encontrado na macro-restrição, demonstrando a predominância de um grupo clonal desse sorovar nos surtos de salmonelose. Uma baixa freqüência de isolados de $S$. Enteritidis resistentes a antimicrobianos foi encontrada, sendo a resistência ao ácido nalidíxico o único perfil encontrado.

Palavras-chave: Salmonella, surtos, quantificação, PFGE

\section{REFERENCES}

1. BAM - Bacteriological Analytical Manual. (1998). (www.cfsan.fda. gov/ ebam/bam-toc.htlm). Appendix 2: Most Probable Number Determination from Serial Dilutions. 8th edition.

2. Bessa, M.C.; Costa, M.; Cardoso, M. (2004). Prevalência de Salmonella sp. em suínos abatidos em frigoríficos sob inspeção federal no Rio Grande do Sul. Braz. J. Vet. Res., 24: 80-84.

3. Bonner, C.; Foley, B.; Wall, P.; Fitzgerald, M. (2001). Analysis of outbreaks of infectious intestinal disease in Ireland 1998 and 1999. Irish Med. J., 94: 142-144.

4. Borowsky, L.; Schmidt, V.; Cardoso, M. (2007). Estimation of most probable number of Salmonella in minced pork samples. Braz. J. Microbiol., 38: 544-546.

5. Cardoso, M.O.; Ribeiro, A.R.; Santos, L.R.; Pilotto, F.; Moraes, H.L.S.; Salle, C.T.P.; Rocha, S.L.S.; Nascimento, V.P. (2006). Antibiotic resistance in Salmonella Enteritidis isolated from broiler carcasses. Braz. J. Microbiol., 37: 368-371.
6. Castagna, S.M.F.; Schwarz, P.; Canal, C.W.; Cardoso, M. (2004) Prevalência de suínos portadores de Salmonella sp. ao abate e contaminação de embutidos tipo frescal. Acta Sci. Vet., 32: 141-147.

7. Clinical and Laboratory Standards Institute (CLSI/NCCLS). (2005). Performance standards for antimicrobial disk susceptibility test Eighth edition: Approved standard M2-A8, CLSI/NCCLS, Wayne, PA, USA.

8. Costalunga, S.; Tondo, E. (2002). Salmonellosis in Rio Grande do Sul, 1997 to 1999. Braz. J. Microbiol., 33: 342-346.

9. Fantasia, M.; Filetici, E. (1994). Salmonella enteritidis in Italy. Int. J. Food Microbiol., 21: 7-13.

10. Fernandes, S.A.; Ghilardi, A.C.R.; Tavechio, A.T.; Machado, A.M.O.; Pignatari, A.C.C. (2003). Phenotypic and molecular characterization of Salmonella Enteritidis strains isolated in São Paulo, Brazil. Rev. Inst. Med. Trop. São Paulo, 45 (2): 59-63.

11. Gebreyes, W.A.; Altier, C. (2002). Molecular characterization of multidrug-resistant Salmonella enterica subsp. enterica serovar Typhimurium isolates from swine. J. Clin. Microbiol., 40, 2813-22.

12. Geimba, M.P.; Tondo, E.C.; Oliveira, F.A.; Canal, C.W.; Brandelli, A. (2004). Serological characterization and prevalence of $s p v$ R genes in Salmonella isolated from foods involved in outbreaks in Brazil. $J$. Food Prot., 67, 1229-1233.

13. Glynn, J.R.; Bradley, D.J. (1992). The relationship between infecting dose and severity of disease in reported outbreaks of Salmonella infection. Epidemiol. Infect., 109 (3): 371-88.

14. Glynn, J.R.; Palmer, S.R. (1992). Incubation period, severity of disease, and infecting dose: evidence from Salmonella outbreak. Am. J. Epidemiol., 136 (11): 1369-77.

15. Gorman, R.; Adley, C. (2004). Characterization of Salmonella enterica serotype Typhimurium isolates from human, food and animal sources in the Republic of Ireland. J. Clin. Microbiol., 42, 23142316.

16. Gudmundsdottir, S.; Hardardottir, H.; Gunnarson, E. (2003). Subtyping of Salmonella enterica serovar Typhimurium outbreak strains isolated from humans and animals in Iceland. J. Clin. Microbiol., 23, 48334835 .

17. Haeghebaert, S.; Sulem, P.; Deroudille, L.; Vanneroy-Adenot, E.; Bagnis, O.; Bouvet, P.; Grimont, F.; Brisabois, A.; Le Querrec, F.; Hervy, C.; Espié, E.; Valk, H.; Vaillant, V. (2003). Two outbreaks of Salmonella Enteritidis phage type 8 linked to the consumption of Chantal cheese made with raw milk, France, 2001. Eurosurv., 8 (78): $151-156$

18. Holcomb, D.L.; Smith, M.A.; Ware, G.O.; Hung, Y.C.; Brackett, R.E.; Doyle, M.P. (1999). Comparison of six dose-response models for use with food-borne pathogens. Risk Anal., 19: 1091-1100.

19. Hurd, H.S.; Gailey, J.K.; McKean, J.D.; Rostagno, M.H. (2001). Rapid infection in market-weight swine following exposure to Salmonella typhimurium-contaminated environment. Am. J. Vet. Res., 62, 1194-1197.

20. Kimura, A.C.; Reddy, V.; Marcus, R. (2004). Chicken consumption is a newly identified risk factor for sporadic Salmonella enterica serotype Enteritidis infections in the United States: a case-control study in FoodNet sites. Clin. Infect. Dis., 38: S244-S252.

21. Liebana, E.; Garcia-Migura, L.; Clouting, C.; Clifton-Hadley, F.A.; Lindsay, E.; Threlfall, E.J.; McDowell, W.J.; Davies, R.H. (2002). Multiple genetic typing of Salmonella enterica serotype Typhimurium isolates of different phage types (DT104, U302, DT204b, and DT49) from animals and humans in England Wales, and Northern Ireland J. Clin. Microbiol., 40 (2): 4450-4456.

22. Liebisch, B.; Schwarz, S. (1996). Molekularbiologische Methoden zur epidemiologischen Typisierung von Salmonellen - Übersichtsreferat. Berl. Münch. Tierärz. Wochensch., 109: 348-354.

23. Mead, P.S.; Slutsker, L.; Dietz, V.; McCaig, L.F.; Bresee, J.S.; Shapiro, C.; Griffin, P.M.; Tauxe, R.V. (1999). Food-related illness and death in the United States. Emer. Infect. Dis., 5: 607-625. 
24. Murmann, L.; Santos, M.C.; Cardoso, M. (2006). Prevalence and level of Salmonella enterica in fresh pork sausages purchased in southern Brazil. 13 International Symposium Salmonella and Salmonellosis, St. Malo, França, p. 443-444.

25. Nadvorny , A.; Figueiredo, D.M.S.; Schmidt, V. (2004). Ocorrência de Salmonella sp. em surtos de doenças transmitidas por alimentos no Rio Grande do Sul em 2000. Acta Sci. Vet., 32 (1): 47-51.

26. Oliveira, S.D.; Bessa, M.J.; Santos, L.R.; Cardoso, M.R.I.; Brandelli, A.; Canal, C.W. (2007). Phenotypic characterization of Salmonella Enteritidis isolates. Braz. J. Microbiol., 38: 720-728.

27. Oliveira, S.D.; Flores, F.S.; Santos, L.R.; Brandelli, A. (2005). Antimicrobial resistance in Salmonella enteritidis strains isolated from broiler carcasses, food, human and poultry-related samples. Int J. Food Microbiol., 97: 297-305.

28. Olsen, J.E.; Brown, D.J.; Skov, M.N.; Christensen, J.P. (1993). Bacterial typing methods suitable for epidemiological analysis. Applications in investigations of salmonellosis among livestock. Vet. Quart., 15: 125-135.

29. Olsen, S.J.; MacKinnon, L.C.; Goulding, J.S.; Bean, N.H.; Slutsker, L. (2000). Surveillance of food-borne disease outbreaks-United States, 1993-1997. CDC Surv. Summ., 49: 1-62.

30. Peresi, J.T.M.; Almeida, I.A.Z.Z.C.; Lima, S.I.; Marques, D.F.; Rodrigues, E.C.A.; Fernandes, S.A.; Gelli, D.S.; Irino, K. (1998). Surtos de enfermidades transmitidas por alimentos causados por Salmonella Enteritidis. Rev. Saúde Pública, 32: 477-483.

31. Rabsch, W.; Tschäpe, H.; Bäumler, A.J. (2001). Non-typhoidal salmonellosis: emerging problems. Microbes Infect., 3: 237-247.

32. Ribeiro, A.R.; Kellermann, A.; Santos, L.R.; Bessa, M.C.; Nascimento, V.P. (2007). Salmonella spp. in raw broiler parts: occurrence, antimicrobial resistance profile and phage typing of the Salmonella Enteritidis isolates. Braz. J. Microbiol., 38: 296-299.

33. Rodrigue, D.C.; Tauxe, R.V.; Rowe, B. (1990). International increase of Salmonella Enteritidis: a new pandemic? Epidemiol. Infect., 105: 21-27.

34. Rose, J.B.; Haas, C.N.; Gerba, C.P. (1995). Linking microbiological criteria for foods with quantitative risk assessment. J. Food Safety, 15: 121-132.

35. Schlundt, J. (2002). New directions in foodborne disease prevention. Int. J. Food Microbiol., 78: 3-17.

36. Schwarz, S.; Liebisch, B. (1994). Pulsed-field gel eletrophoretic identification of Salmonella enterica serovar Typhimurium live vaccine strain Zoosaloral H. Lett. Appl. Microbiol., 19: 469-472.

37. Tavechio, A.T.; Ghilardi, A.C.R.; Peresi, J.T.M.; Fuzihara, T.O.; Yonamine, E.K.; Jakabi, M.; Fernandes, S.A. (2002). Salmonella serotypes isolated from nonhuman sources in São Paulo, Brazil, from 1996 through 2000. J. Food Prot., 65, 1041-1044.

38. Varnam, A.H. (1991). Foodborne pathogens: an ilustrated text. Aylesbury: Wolfe, p. 51-462.

39. Vaz, C.S.L. (2007). Determinação da diversidade fenotípica e genotípica de Salmonella enterica subsp. enterica sorovar Enteritidis no Rio Grande do Sul. Porto Alegre, 133 p. (PhD Thesis, Faculdade de Veterinária, UFRGS).

40. Vieira-Pinto, M.; Tenreiro, R.; Martins, C. (2006). Unveiling contamination sources and dissemination routes of Salmonella sp. in pigs at a Portuguese slaughterhouse through macrorestriction profiling by pulsed-field electrophoresis. Int. J. Food Microbiol., 110: $77-84$ 